\title{
Two new species of the genus Crenicichla Heckel, 1840 from the upper rio Uruguay drainage (Perciformes: Cichlidae)
}

\author{
Carlos A. S. de Lucena
}

Two new species of the genus Crenicichla from the upper rio Uruguay basin are described, Crenicichla hadrostigma and $C$. empheres. Both are included in the C. missioneira species group along with C. missioneira, C. minuano, C. tendybaguassu, C. igara, and C. jurubi, all occurring in the upper and middle rio Uruguay drainage. Crenicichla hadrostigma is distinguished by the conspicuous ocellated posttemporal blotch, absence of a humeral spot and lateral band, and the presence in males of nine to 16 narrow vertical bars extending from the dorsum to a horizontal line that passes through the lower edge of pectoral axilla. Crenicichla empheres is distinguished from the other species of the missioneira-group by the presence of six to eight horizontally elongate dark blotches along the middle portion of the body, slightly below the upper lateral line, absence of a lateral band, presence in males of numerous dark and irregularly arranged spots on nape, back, and sides of body, and isognathous mouth. A key to the species from rio Uruguay basin is presented.

São descritas duas novas espécies do gênero Crenicihla da bacia do alto rio Uruguai, Crenicichla hadrostigma e C. empheres. Ambas pertencem ao grupo-missioneira composto por C. missioneira, C. minuano, C. tendybaguassu, C. igara e C. jurubi, todas ocorrendo na bacia do alto e médio rio Uruguai. Crenicichla hadrostigma distingue-se dessas espécies pela conspícua mancha escura ocelada pós-temporal, ausência de mancha umeral e de faixa escura longitudinal e, pela presença de nove a 16 listras verticais escuras em exemplares machos que se estendem desde o dorso até linha horizontal que passa pela axila inferior da nadadeira peitoral. Crenicichla empheres distingue-se das demais espécies do grupo-missioneira, pela presença de seis a oito manchas retangulares escuras na linha média do corpo logo abaixo da linha lateral superior, ausência de faixa escura longitudinal, machos com pequenas manchas ou pontos escuros espalhados no dorso e laterais do corpo, e boca isognata. Uma chave para as espécies da bacia do rio Uruguai é fornecida.

Key words: Santa Catarina, Rio Grande do Sul, Crenicichla missioneira species group.

\section{Introduction}

Crenicichla is the most speciose genus of the family Cichlidae, comprising 77 valid species in cis-Andean South America (Kullander, 2003; Kullander \& Lucena, 2006). Thirteen species inhabit the state of Rio Grande do Sul where they are recognized by vernacular names of Joaninhas or Micholas (Lucena \& Kullander, 1992). To help the identification of the species, the genus has been divided into five to eight species-groups (Ploeg, 1991; Kullander \& Lucena, 2006).

In the last taxonomic revision of the genus in southern Brazil, Lucena \& Kullander (1992) recognized 11 species from the rio Uruguay drainage, included in two endemic groups: the C. missioneira and C. scottii. The former group is recognized by the following combination of characters: smooth preopercular margin, suborbital stripe reduced to one or a few small spots just below the eye; humeral spot absent; ocellated caudal spot present, situated immediately at the base of the caudal fin, in males fragmented into smaller spots; $50-74$ scales in E1 row, and 3-6 rows of depressible teeth.

An ichthyological survey in the rio Chapecó and the upper rio Uruguay, yielded specimens with color patterns not found in other species of Crenicichla, herein described as two new species of the C. missioneira species group.

\section{Material and Methods}

The material examined is deposited in the Museu de Ciências e Tecnologia, Pontifícia Universidade Católica do Rio Grande do Sul, Porto Alegre (MCP) and Asociación Ictiologica, La Plata (AI). Additional comparative specimens are those listed in Lucena \& Kullander (1992). Measurements and counts follow Kullander (1986). E1 scale counts and the color pattern nomenclature follow Lucena \& Kullander (1992).

Museu de Ciências e Tecnologia, Pontifícia Universidade Católica do Rio Grande do Sul. Av. Ipiranga 6681. 90619-900 Porto Alegre, RS, Brazil. lucena@pucrs.br 
The lower pharyngeal tooth plate was prepared following the method of Taylor \& Van Dyke (1985). The limits of the upper rio Uruguay drainage follow Lucena \& Kullander (1992).

\section{Results}

Key to the Crenicichla species from the rio Uruguay drainage (expanded from Lucena \& Kullander, 1992):

1. Preopercle serrated, suborbital stripe present .2

1'. Preopercle with smooth posterior margin. Suborbital stripe absent or reduced to one or few small spots C. vittata

2. More than 75 scales in E1 row

2'. Less than 60 scales in E1 row ... 3

3. Body flank with several regular parallel rows of small dark spots C. scottii

3 '. Body flank without spots or with scattered dark spots not forming rows .

4. A dark blotch in the humeral region C. lepidota

4'. Absence of a dark blotch in the humeral region ............... 5

5. Males with numerous scattered dark spots on the flank; females with plain sides or indistinct spots; dorsal fin of males with spots on both spinous and soft portions ........ C. gaucho

$5^{\prime}$. Both males and females without scattered dark spots on the flank; dorsal fin of males with spots restricted to the soft portion C. prenda

6. Absence of rows of blotches along the middle of the body flank and of lateral band; a conspicuous ocellated posttemporal spot, its depth always greater than half orbital diameter, frequently equal or larger than orbital diameter. C. hadrostigma

6'. Presence of rows of blotches along the middle of the body flank or a lateral band; ocellated posttemporal spot equal or smaller than the half orbital diameter or absent 7

7. Prominent lateral band incorporating the caudal spot. Upper and lower lips with contrasting bilateral black spots anteriorly. A dark stripe on the front marking the ascending process of the premaxilla C. celidochilus

7'. A row of blotches along the middle portion of the body flank; very rarely the blotches contiguous to form a lateral band. A dark spot at the tip of the lower jaw present or absent, but no other spots on the lower lip. No dark stripe along the premaxillary ascending process ......................... 8

8. Numerous dark spots scattered over the body flank ...... 9

8 '. Body flank without dark spots or present on the caudal peduncle of males only 11

9. Jaws isognathous or lower jaw slightly prognathous; lower pharyngeal tooth plate thick, with molariform or short, strong and subconical teeth 10

9'. Lower jaw distinctly prognathous; lower pharyngeal tooth plate dorsoventrally compressed, all teeth conical ........... C. igara

10. Males with numerous spots scattered over flank but not on the head; 6 to 8 slightly elongate blotches along middle portion of the body flank; all blotches not fragmented into smaller spots; spots on the base of the membranes of the spinous and soft dorsal fin comparatively larger than remaining spots C. empheres

10'. Males and females with numerous spots scattered over back, flank, and sometimes in the head; sometimes the last three or four blotches contiguous or fragmented into smaller spots; spots on the base of the spinous and soft membranes of dorsal fin smaller, or same size, than remaining spots C. jurubi

11. Upper and lower lip folds continuous, very wide, with median anterior lobes; both jaws but especially the upper pointed C. tendybaguassu

11'. Upper and lower lip folds interrupted anteriorly, lips neither lobed nor particularly thick; jaws rounded anteriorly ..

12

12. Jaws isognathous; sometimes with a continuous lateral band. C. minuano 12'. Jaws prognathous; lateral band absent C. missioneira

\section{Crenicichla hadrostigma, new species}

(Figs. 1, 2)

Holotype. MCP 40959. Male, 100.1 mm SL. Brazil, state of Santa Catarina, rio Chapecó, on the old road Coronel de Freitas-Quilombo, Vila São Miguel, Coronel de Freitas, (2651'26”S, 5244'29”W), 23 Jan 2006, C. Lucena, V. Bertaco, E. Pereira \& J. da Silva.

Paratypes. 31 specimens, 79.7-113.5 mm SL, all from Brazil. Santa Catarina: MCP 40051 (86,3-91,2mm CP, females), MCP 40079 (3, 79.7-100.8 mm SL, females), MCP 40082 (16, 36.1-93.3 mm SL, measured only 3 larger males), MCP 40110 (2, 100.0-113.0 mm SL, males), and MCP 40134 (1, 94.6 mm SL, female), same data as holotype; MCP 19037 (2, 95.6-98.4 mm SL, males), rio Uruguay, Pedra da Fortaleza, Itapiranga, 31 May 1997, L. Hahn, et al.; MCP 22035 (5, 98.9-111.0 mm SL), rio Uruguay, near Pedra da Fortaleza, Itapiranga, 27¹1'42"S 5338'34"W, 14 Jan 1999, L. Hahn et. al.; MCP 22036 (1, $92.5 \mathrm{~mm}$ SL, female), same data as MCP 22035; MCP 33936 (4, 101.5-113.5 mm SL, males), rio Chapecó, Coronel de Freitas, 265' S 5242'W, Feb 2003, Leandro Baucke. Rio Grande do Sul: MCP 40067 (7, 80.1-92.3mm SL), rio Uruguay, farm on the road Barra do Guarita-Palmitinho, Barra do Guarita, 27¹1'47'S, 53³9'07'W, 26 Jan 2006, C. Lucena \& V. Bertaco, E. Pereira \& J. da Silva.

Non-types: Brazil: Rio Grande do Sul: MCP 40874 (1, $106.3 \mathrm{~mm}$ $\mathrm{SL})$, rio Uruguay, farm on the road Barra do Guarita-Palmitinho, Barra do Guarita, 27¹1'47'S 053³9'07' W, 26 Jan 2006, C. Lucena et. al. Argentina: AI 220 (1, $72.8 \mathrm{~mm}$ SL, photo examined), rio Uruguay, $22 \mathrm{Km}$ to south of San Javier, Itacaruare, Misiones.

Diagnosis. Crenicichla hadrostigma is readily distinguished from all other species of Crenicichla by having a conspicuous ocellated posttemporal spot, always greater than half orbital diameter, frequently equal or larger than orbital diameter ( $v s$ smaller or absent). From the C. missioneira species group it also differs from $C$. igara and $C$. jurubi, by the absence, in both sexes, of numerous spots scattered over the back and sides and by the presence, in males, of 11 to 16 narrow vertical single or double-bars across the sides from just below the first spine of dorsal-fin to the first and second 
or fourth and fifth soft ray of the same fin $v s$ five to seven elongate dark blotches varying in appearance. The narrow vertical bars can occur in C. tendybaguassu, C. minuano and C. missioneira. It is distinguished from C. tendybaguassu by the normal vs greatly thickened lips. The isognathous mouth distinguishes $C$. hadrostigma from $C$. missioneira which has the lower jaw longer than the upper jaw, and it can be distinguished from $C$. minuano and $C$. celidochilus by the absence of a lateral band ( $v s$ presence).

Description. Measurements in Table 1. Meristic data in Table 2.

Body relatively deep, body depth $21.9-27.0 \%$ SL. Head deeper than wide. Caudal peduncle longer than deep. Snout short, rounded from above, blunt in lateral view. Jaws isognathous. Ascending premaxillary processes reaching to or almost to vertical through middle of orbit. Maxilla reaching to vertical through anterior margin of orbit. Upper lip thick and wide, folds not continuous but interrupted at the wide symphyseal region. Postlabial skin fold margin rounded. Orbit supralateral, not visible from below, chiefly in anterior half of head. Nostrils dorsolateral, about halfway between orbit and margin of postlabial skin fold, low tubular margin but no anterior marginal skin flap. Posterior margin of preopercle smooth or with a few irregularly distributed projections.

Flank scales strongly ctenoid. Scales on head, anteriorly on back (above about anterior $1 / 4$ of lateral line), along dorsal fin base, on chest and belly, and near anal-fin base cycloid.
Predorsal scales small, superficially embedded in skin, extending forward almost to transverse frontal lateralis canal. Prepelvic scales very small, superficially embedded in skin. Cheek fully scaled; 6-11 scale rows below eye, embedded in skin. Interopercle naked. Circumpeduncular scale rows 11-13 dorsally, 12-14 ventrally (total 24-27).

Scales between upper lateral line and dorsal-fin base 1116 anteriorly, 4-5 posteriorly; 2-3 scale rows between lateral lines. Anterior upper lateral-line scales slightly larger and more elongate than adjacent scales, remaining lateral-line scales nearly the same size as adjacent scales. Dorsal, anal, pectoral, and pelvic fins without scales. Caudal-fin squamation marginally extending to near middle of fin.

First dorsal-fin spine about 1/4-1/5 length of last; spines increasing in length to last but subequal from about 10 th. Distal margin of dorsal fin rounded in both sexes, 7 th-8th rays reaching slightly to first $1 / 3$ of caudal fin. Soft anal fin with pointed tip, in both sexes reaching to base of caudal fin. Caudal fin rounded. Pectoral fin rounded, reaching about halfway to anal fin. Pelvic fin inserted well posterior to vertical through pectoral axilla, with acuminate tip, second ray longest, reaching about halfway to spinous anal fin or slightly beyond.

All teeth pointed, erect or slightly recurved. Teeth of outer row distinctly larger than teeth of inner row and larger anteriorly than posteriorly. Upper jaw with 5-6 inner tooth rows anteriorly; outer row teeth slightly movable or fixed, $3 / 4$ length of dentigerous arm of premaxilla, one inner row almost as

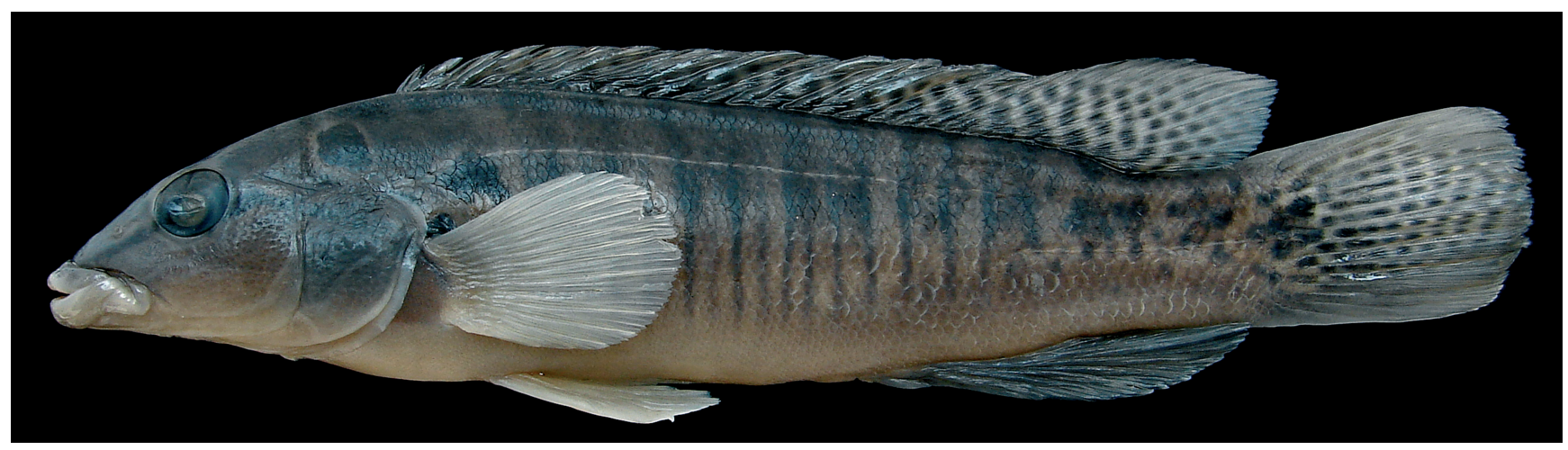

Fig. 1. Crenicichla hadrostigma, holotype, rio Chapecó, Coronel de Freitas, Santa Catarina, MCP 40959 (100.1 mm SL, male).

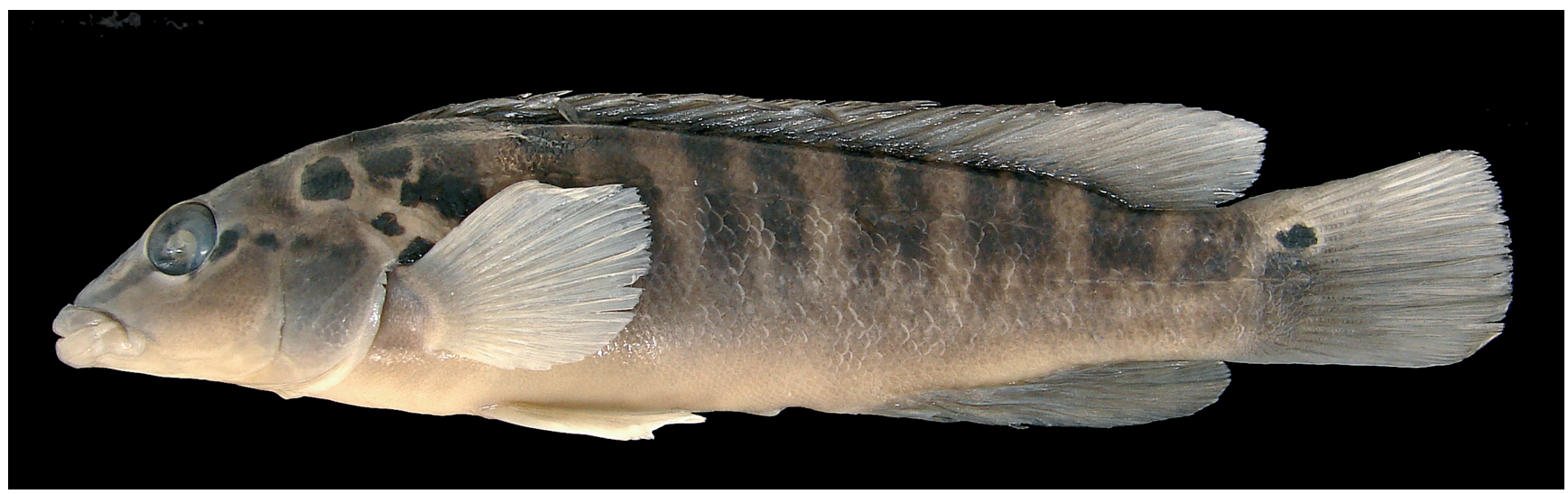

Fig. 2. Crenicichla hadrostigma, paratype, rio Chapecó, Coronel de Freitas, Santa Catarina, MCP 40079 (100.8 mm SL, female). 
long; inner teeth fully depressible. Lower jaw with 3-4 inner tooth rows anteriorly; outer row teeth fixed, inner teeth depressible.

Microbranchiospines present on both sides of all gill arches.

Lower pharyngeal tooth plate in specimen $92.5 \mathrm{~mm} \mathrm{SL}$ (Fig. 3), strongly depressed dorsoventrally, stout, length of dentigerous area $64 \%$ of its width. Medial and posteromedial teeth, strong, enlarged but not molariform. All other teeth conical, without retrorse cusp. 15-16 teeth in posterior row, 6 in median row.

Coloration in alcohol. Usually dark spot at tip of lower jaw. Upper lip gray. Dark brown preorbital stripe from orbit across upper lip and around tip of lower jaw. Dark brown postorbital stripe running straight from orbit to dorsal end of gill cleft, sometimes interrupted or reduced to a blackish spot immediately posterior to orbit. In a few specimens preorbital stripe curved along ventral border of orbit. Suborbital stripe absent or reduced to a spot at margin of orbit. One specimen (MCP 22035 ) with three or four spots just below orbit. Nuchal markings other than posttemporal spot faint. Posttemporal spot prominently ocellated; always greater than half orbital diam-

Table 1. Morphometrics of Crenicichla hadrostigma. $\mathrm{SD}=$ standard deviation; $\mathrm{n}=$ number of specimens.

\begin{tabular}{|c|c|c|c|c|c|c|}
\hline \multirow[b]{2}{*}{ Measurements } & \multicolumn{6}{|c|}{ Range } \\
\hline & $\mathrm{n}$ & Holotype & Min. & Max. & Mean & SD \\
\hline \multirow[t]{2}{*}{ Standard length (mm) } & & 100.1 & 31 & 79.7 & 113.5 & \\
\hline & \multicolumn{6}{|c|}{ Percents of Standard length } \\
\hline Body depth & 31 & 24.0 & 21.9 & 27.0 & 24.6 & 1.456 \\
\hline Caudal peduncle length & 31 & 18.0 & 13.5 & 20.4 & 16.9 & 1.852 \\
\hline Caudal peduncle depth & 31 & 12.4 & 10.8 & 13.3 & 12.0 & 0.627 \\
\hline Last dorsal spine length & 31 & 13.0 & 11.2 & 20.8 & 13.4 & 1.631 \\
\hline Pectoral fin length & 31 & 17.6 & 17.6 & 20.6 & 19.2 & 0.795 \\
\hline \multirow[t]{2}{*}{ Head length } & 30 & 31.6 & 29.0 & 34.4 & 30.6 & 1.126 \\
\hline & \multicolumn{6}{|c|}{ Percents of Head length } \\
\hline Head depth & 30 & 48.4 & 46.8 & 59.0 & 53.5 & 2.832 \\
\hline Snout & 30 & 36.2 & 32.3 & 44.7 & 37.0 & 2.731 \\
\hline Orbital diameter & 30 & 21.7 & 19.5 & 24.3 & 22.1 & 1.119 \\
\hline Interorbital width & 30 & 12.5 & 11.6 & 22.6 & 14.7 & 2.122 \\
\hline Upper jaw length & 30 & 30.8 & 21.0 & 35.8 & 31.7 & 2.762 \\
\hline Lower jaw length & 30 & 36.2 & 33.7 & 42.4 & 38.2 & 2.215 \\
\hline
\end{tabular}

eter, frequently equal or larger than orbital diameter; in some specimens posttemporal spot extending to anterior lateral line. A blackish, prominent blotch just above pectoral axilla, sometimes subdivided and with a dorsal extension.

Prominent ocellated anterior spot may be present, in both sexes, on first vertical bar in females, or on first stripe-pair in males. Ocellated caudal spot present in both sexes; sometimes fragmented into smaller spots.

Males (Fig. 1) with 11 to 16 narrow vertical single or doublebars across sides from below first dorsal-fin spine to first and second or fourth and fifth dorsal-fin ray. Some specimens with a blackish area sometimes extending to dorsum, between each stripe-pair, just below the anterior lateral line. Two blackish blotches on dorsal margin of caudal peduncle. Numerous scattered dark brown spots on caudal peduncle.

Dorsal fin grayish with 3-4 irregular rows dark spots on the spinous portion and several additional rows of dark spots on the soft portion. Anal fin blackish with few dark spots on final portion. Caudal fin vividly patterned with dark spots except posterodorsally and posteroventrally. Some specimens collected in rio Uruguay (MCP 40067), both males and females, show basic pattern of coloration darker compared to specimens from rio Chapecó. One male, MCP 40874, from rio

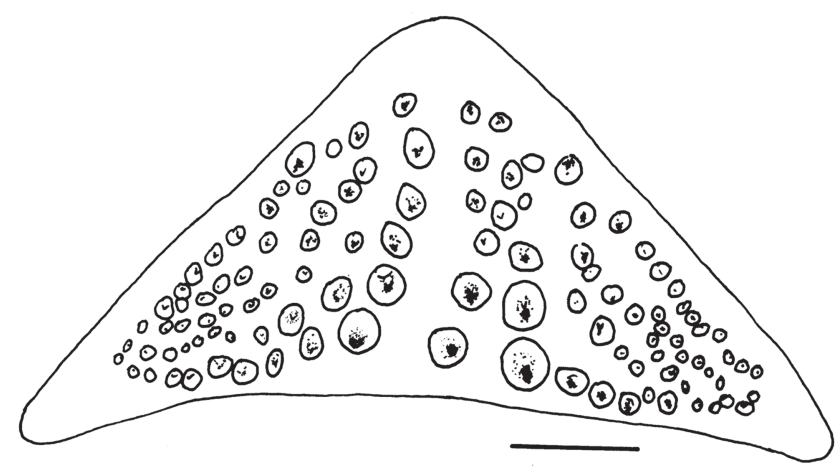

Fig. 3. Crenicichla hadrostigma, lower pharyngeal tooth plate in occlusal view, MCP 22036 (92.5 mm SL, female). Scale bar: $1 \mathrm{~mm}$.

Table 2. Frequency counts of meristic characters of Crenicichla hadrostigma. MCP 40959, *=Holotype.

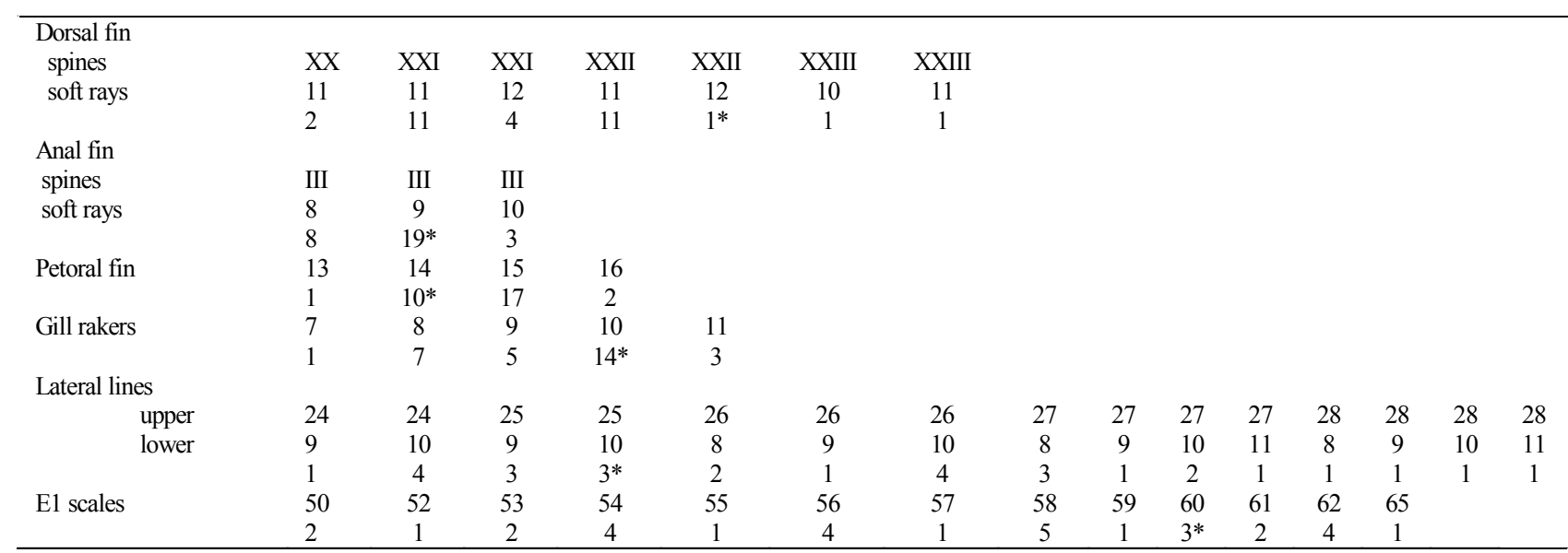


Uruguay, has the body coloration so dark that it is difficult to recognize the posttemporal spot and therefore it is not included among the type-material.

Females (Fig. 2) have nine to ten vertical dark bars, alternating with light areas, along the side from below first spines of dorsal fin to fourth and fifth soft rays of dorsal fin. Last four bars may be joined pair to pair just below anterior lateral line. Two additional bars on dorsal margin of caudal peduncle. Dorsal, anal, and caudal fins smoky. One female (MCP 22036) with ocellated dark spot between dorsal spines 13-15. Pectoral and pelvic fins whitish in both sexes.

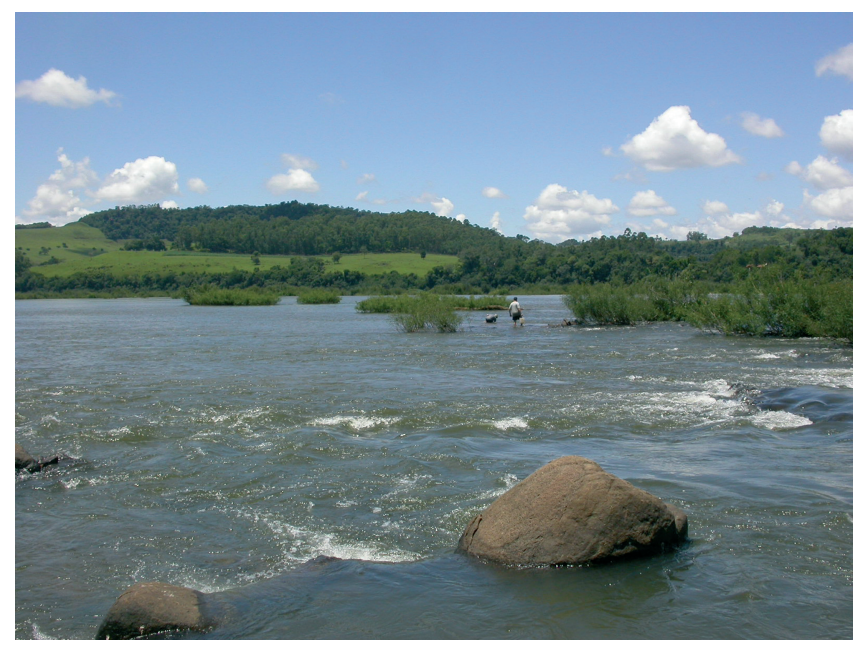

Fig. 4. Rio Uruguay, on the road Barra do Guarita-Palmitinho, Barra do Guarita, Rio Grande do Sul. General view of the explored riffle stretch where were captured specimens of $C$. hadrostigma.

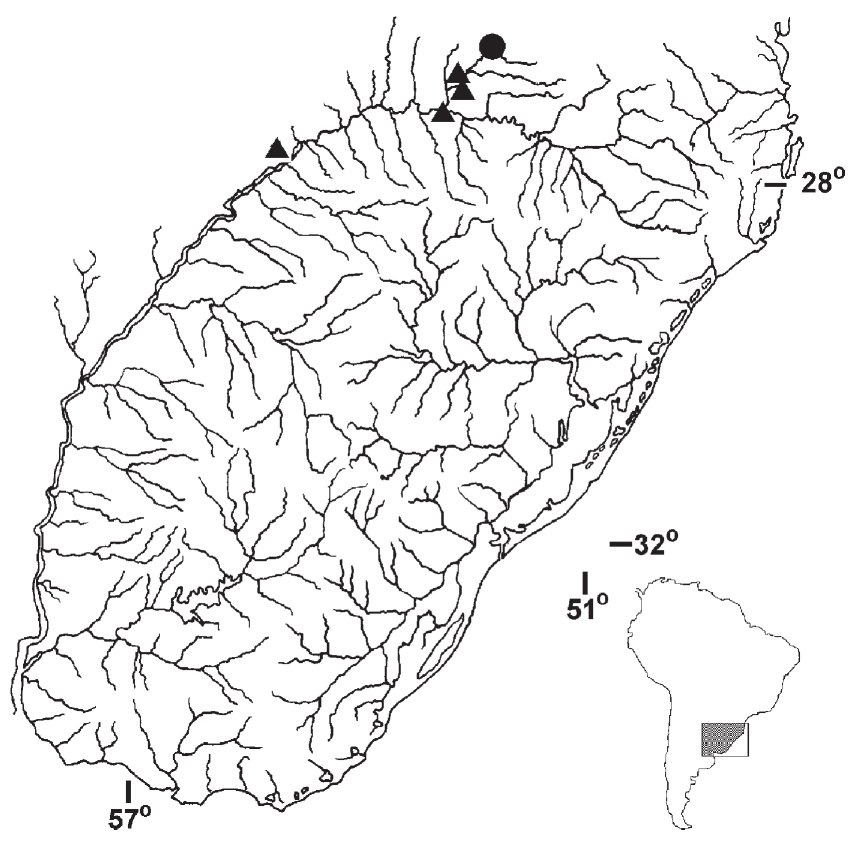

Fig. 5. Collecting localities of Crenicichla hadrostigma (triangles) and Crenicichla empheres (black dot).
Color in life. Males grayish. Vertical bars dark with a blackish area, between each bar-pair, just below the anterior lateral line or bars slightly darker near the dorsum without blackish median area. Dorsal, anal, caudal and pelvic fins yellow. Dorsal, anal, and caudal fins with scattered black spots forming rows on their surfaces. Pectoral fin whitish. Females alternating dark bars and whitish areas. All fins white or yellow. Dorsal fin with a red bar on the spinous portion and middle base of soft-ray portion; not reaching to its tip. A red or orange horizontal bar from pectoral-fin axilla to vertical across anus. Ventral border of opercle red or yellow. Both sexes with posttemporal spot and anterior ocellated spot, when present, margined by a yellow ring. Caudal spot dark margined by a yellow ring.

Stomach contents. One female, $92.5 \mathrm{~mm}$ SL (MCP 22036), with mollusk shells.

Distribution. Rio Uruguay (Fig. 4) and rio Chapecó, rio Uruguay drainage (Fig. 5).

Etymology. The epithet hadrostigma from Greek, hadros $=$ well-developed and stigma $=$ spot, mark, in reference to the prominent posttemporal spot diagnostic of the species. An adjective.

Comments. The specimen MCP 22036 (1, 92.5mm SL, female) was removed from the stomach of a specimen of Salminus brasiliensis.

\section{Crenicichla empheres, new species}

(Figs. 6, 7)

Holotype. MCP 40960. Male, 104.4 mm SL. Brazil, state of Santa Catarina, rio Chapecó, on the road Abelardo Luz-Coronel Firmino Martins, Abelardo Luz, (26 $\left.33^{\prime} 35^{\prime \prime} \mathrm{S}, 5^{\circ} 19^{\prime} 41^{\prime \prime W}\right), 24$ Jan 2006, C. Lucena, V. Bertaco, E. Pereira \& J. da Silva.

Paratypes. 27 specimens, 85.1-140.7mm SL, all from Brazil. Santa Catarina: MCP 40176 (29, 23.8-139.7 mm SL, one specimen 93.2 $\mathrm{mm} \mathrm{SL}, \mathrm{c} \& \mathrm{~s})$ same data as holotype.

Diagnosis. Distinguished from other species of the $C$. missioneira group by the presence of six to eight slightly elongate blotches along middle portion of the body flank below the upper lateral line scale row, absence of a lateral band, numerous spots scattered over back, sometimes forming a reticulated pattern, and sides in males, and isognathous mouth. Crenicichla empheres is most similar to C. igara and C. jurubi in color pattern, but both males and females of the latter species show the same scattered spots including those on the head and opercle $v s$ absent in females and males of Crenicichla empheres which has the spots confined to the lateral of body. Besides, C. jurubi may have the last three or four blotches contiguous without lighter space between them and/or mixing with the spotted pattern of the body. It differs from $C$. igara by the isognathous mouth (vs prognathous). Besides, females of $C$. empheres may show ocellated spot on the dorsal fin vs absent in C. igara. 
Description. Measurements in Table 3. Meristic data in Table 4.

Body relatively deep, body depth $18.8-23.4 \%$ SL. Head wider than deep. Caudal peduncle longer than deep. Snout short, rounded from above, blunt in lateral view. Jaws isognathous. Ascending premaxillary processes reaching to or almost to $1 / 2$ of orbit.

Maxilla reaching to a vertical from anterior margin of orbit. Upper lip thick and wide, folds not continuous but interrupted into a symphyseal wide extent. Postlabial skin fold margin rounded. Orbit supralateral, not visible from below, chiefly in anterior half of head. Nostrils dorsolateral, about halfway between orbit and margin of postlabial skin fold, low tubular margin but no anterior marginal skin flap. Posterior margin of preopercle smooth or with a few irregularly distributed projections.

Flank scales strongly ctenoid. Scales on head, anteriorly on back (above about anterior $1 / 4$ of lateral line), along dorsal fin base, chest, and on belly below line from lower edge of pectoral axilla to anal fin origin and near anal-fin base, cycloid. Predorsal scales small, superficially embedded in skin, extending forward almost to transverse frontal lateralis canal. Prepelvic scales very small, superficially embedded in skin. Cheek fully scaled; 7-12 scale rows below eye, embedded in skin. Interopercle naked. Circumpeduncular scale rows 10-13 dorsally, 11-14 ventrally (total 24-28).

Scales between upper lateral line and dorsal-fin base 9-12 anteriorly, 4-5 posteriorly; 2-3 scale rows between lateral lines. Anterior upper lateral-line scales slightly larger and more elongate than adjacent scales, remaining lateral-line scales nearly the same size as adjacent scales. Dorsal, anal, pectoral, and pelvic fins without scales. Caudal-fin squamation marginally extending to near middle of fin.

First dorsal-fin spine about 1/4-1/5 length of last; spines increasing in length to last but subequal from about 11 th. Distal margin of dorsal fin pointed in both sexes, 7 th- 8 th rays reaching slightly to first $1 / 3$ of caudal fin. Soft anal fin with pointed tip, in both sexes not reaching to base of caudal fin. Caudal fin truncate or slightly rounded. Pectoral fin rounded, reaching about halfway to anal fin. Pelvic fin inserted well posterior to vertical through pectoral axilla, with acuminate tip, second ray longest, reaching about halfway to spinous anal fin.

All teeth pointed, erect or slightly recurved. Teeth of outer row distinctly larger than the inner and larger anteriorly than posteriorly. Upper jaw with 5-6 inner tooth rows anteriorly; outer row teeth slightly movable or fixed, $3 / 4$ the length of the dentigerous arm of the premaxilla, one inner row almost as long; inner teeth fully depressible. Lower jaw with 4-5 inner tooth rows not distinctive; outer row teeth fixed, inner depressible.

Microbranchiospines present on both sides of all gill arches.

Lower pharyngeal tooth plate in $93.2 \mathrm{~mm}$ SL (female) (Fig. 8) depressed dorsoventrally, length of dentigerous area $45 \%$ of its width. Medial and posteromedial teeth, strong, larger than others and with a central cusp. All other teeth conical, without retrorse cusp. 19-22 teeth in posterior row, 7 in median row.

Coloration in alcohol. Upper and lower lips grayish. Dark brown preorbital stripe from orbit across upper lip and around

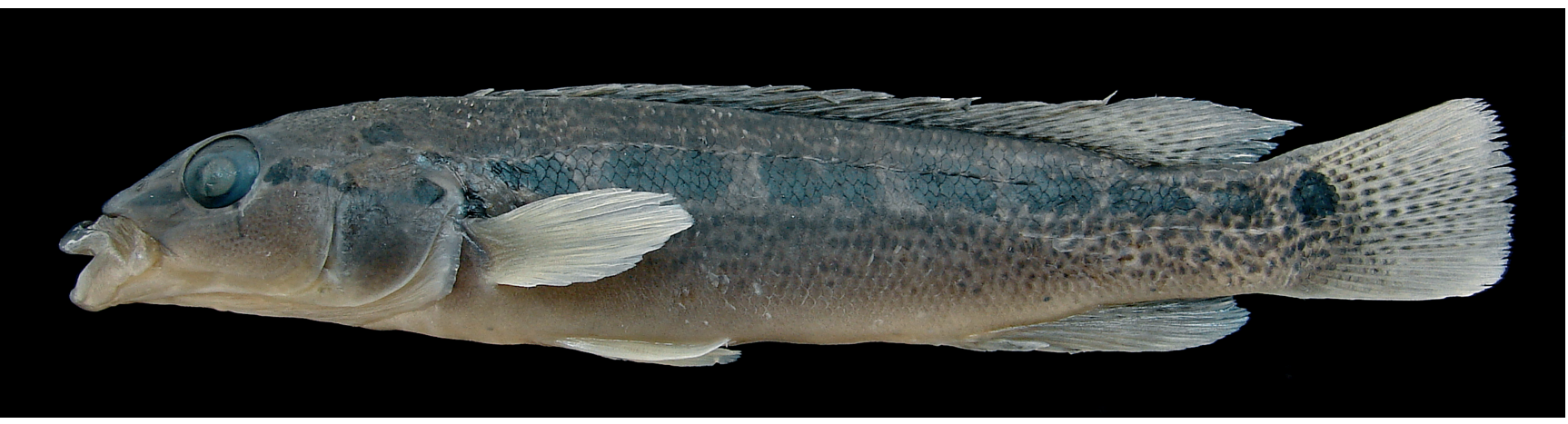

Fig. 6. Crenicichla empheres, holotype, rio Chapecó, Abelardo Luz, Santa Catarina, MCP 40960 (104.4 mm SL, male).

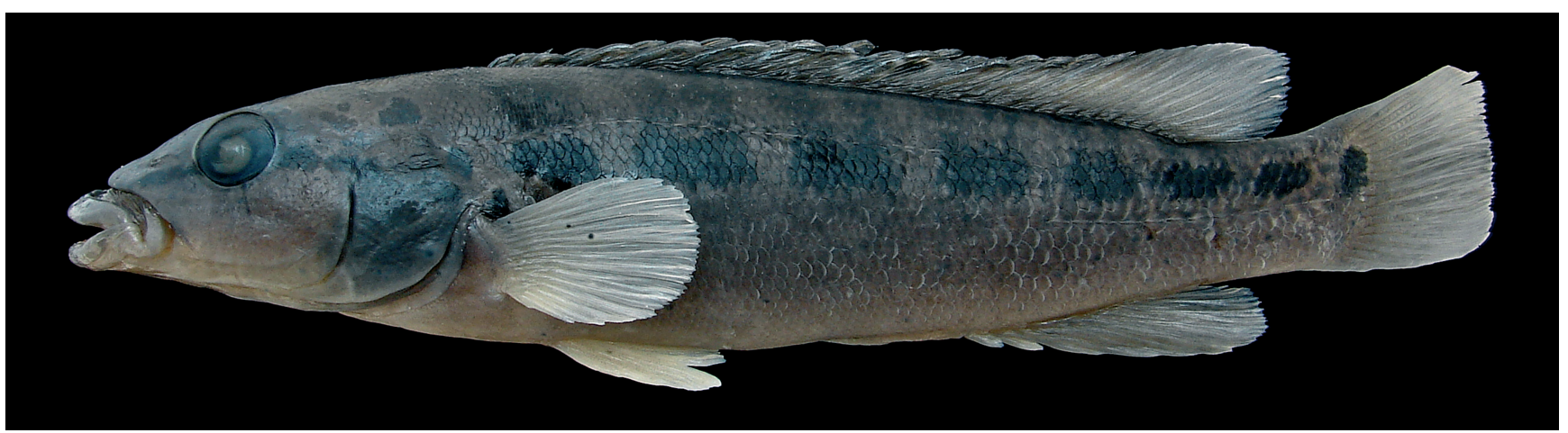

Fig. 7. Crenicichla empheres, paratype, rio Chapecó, Abelardo Luz, Santa Catarina, MCP 40176 (124.3 mm SL, female). 
tip of lower jaw. Dark brown postorbital stripe running straight from orbit to dorsal end of gill cleft, sometimes interrupted or terminate just posterior to preopercle. In general larger near orbit. Suborbital stripe reduced to a spot at margin of orbit or two to five little points below orbit. Nuchal markings other than posttemporal spot faint. Posttemporal spot prominently ocellated but smaller than half orbital diameter. A blackish, prominent blotch just above pectoral axilla, occasionally with a dorsal extension to first lateral line scales. Prominent ocellated anterior spot may be present on first vertical bar (females) or first stripe-pair (males). Large and rounded black occelated caudal spot.

Six to eight elongate blackish blotches along middle portion of body flank, all immediately below canal series upper lateral line. One wide or two narrow pale brownish bars extending up from each of five or six blotches, and single wide bars from posterior two blotches to dorsal margin of caudal peduncle.

Nape, back, and sides with numerous dark irregularly arranged spots in males, occasionally forming reticulate pattern (Fig. 6) especially above the upper lateral line. Dorsal fin smoky with grayish margin and two or three rows of dark spots on spinous portion, and many small dark spots on soft

Table 3. Morphometrics of Crenicichla empheres. $\mathrm{SD}=$ standard deviation; $\mathrm{n}=$ number of specimens.

\begin{tabular}{|c|c|c|c|c|c|c|}
\hline \multirow[b]{2}{*}{ Measurement } & \multicolumn{6}{|c|}{ Range } \\
\hline & $\mathrm{n}$ & Holotype & Min. & Max. & Mean & $\mathrm{SD}$ \\
\hline \multirow[t]{2}{*}{ Standard length (mm) } & 28 & & 85.1 & 140.7 & 112.4 & 14.681 \\
\hline & \multicolumn{6}{|c|}{ Percents of Standard length } \\
\hline Body depth & 28 & 20.1 & 18.8 & 23.4 & 20.6 & 1.053 \\
\hline Caudal peduncle length & 28 & 16.9 & 16.9 & 20.8 & 18.5 & 0.949 \\
\hline Caudal peduncle depth & 28 & 10.2 & 9.9 & 12.2 & 10.6 & 0.526 \\
\hline Last dorsal spine length & 28 & 10.4 & 9.9 & 12.6 & 10.8 & 0.659 \\
\hline Pectoral fin length & 28 & 18.5 & 15.0 & 20.6 & 17.0 & 1.368 \\
\hline \multirow[t]{2}{*}{ Head length } & 28 & 33.3 & 30.3 & 34.5 & 32.5 & 1.001 \\
\hline & \multicolumn{6}{|c|}{ Percents of Head length } \\
\hline Head depth & 28 & 46.8 & 45.2 & 56.0 & 49.6 & 2.603 \\
\hline Snout length & 28 & 11.7 & 30.0 & 40.8 & 35.3 & 2.466 \\
\hline Orbital diameter & 28 & 20.4 & 16.4 & 22.4 & 20.1 & 1.448 \\
\hline Interorbital width & 28 & 13.5 & 12.6 & 18.9 & 15.3 & 1.645 \\
\hline Upper jaw length & 28 & 30.4 & 26.1 & 33.9 & 30.2 & 1.821 \\
\hline Lower jaw length & 28 & 40.2 & 34.4 & 44.0 & 40.9 & 2.247 \\
\hline
\end{tabular}

portion; spots large at the base compared to the remaining spots. Caudal fin smoky with numerous small dark spots except posteroventrally and posterodorsally. Anal fin smoky with numerous small dark spots distally. Pelvic fin whitish. Pectoral fin grayish.

Dorsal fin in females (Fig. 7) smoky with darker margin; young occasionally with a short small row of black spots on dorsal-fin base. All females, except three specimens (86.5 94.4, and $104.2 \mathrm{~mm} \mathrm{SL}$ ) possess a large black, slightly horizontally extended blotch between dorsal spines 11-14, 13-16, 14-17, or 16-18; blotch narrowly margined by hyaline zone. Anal fin grayish, occasionally with a few dark spots distally. Caudal fin grayish and immaculate or with only a few dark spots on median rays. Pelvic fin whitish. Pectoral fin grayish.

Stomach contents. One female $93.2 \mathrm{~mm} \mathrm{SL}$ (MCP 40176), with aquatic insect larvae.

Distribution. Rio Chapecó, upper rio Uruguay drainage (Fig. 5).

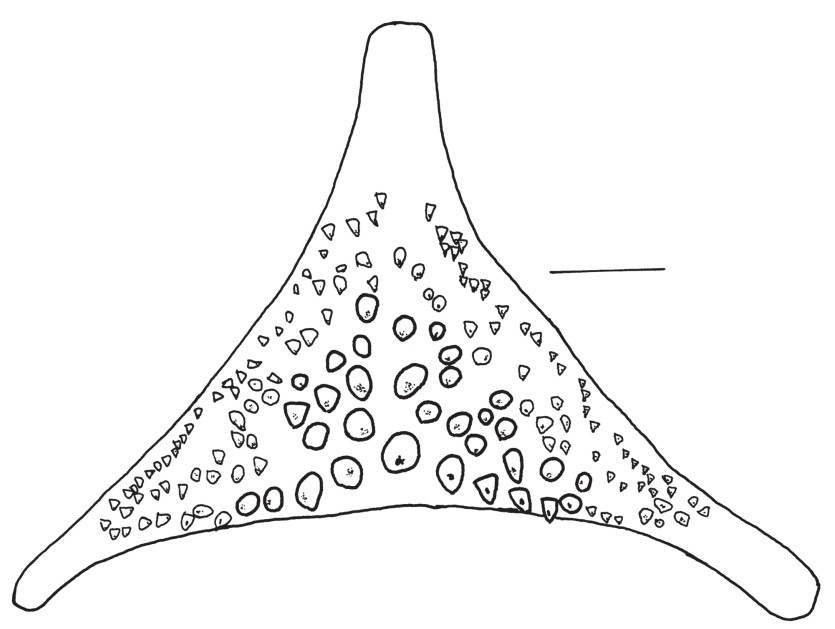

Fig. 8. Crenicichla empheres, lower pharyngeal tooth plate in occlusal view, MCP 40176 (93.2 mm SL, female). Scale bar: $1 \mathrm{~mm}$.

Table 4. Frequency counts of meristic characters of Crenicichla empheres. MCP 13585, *=Holotype.

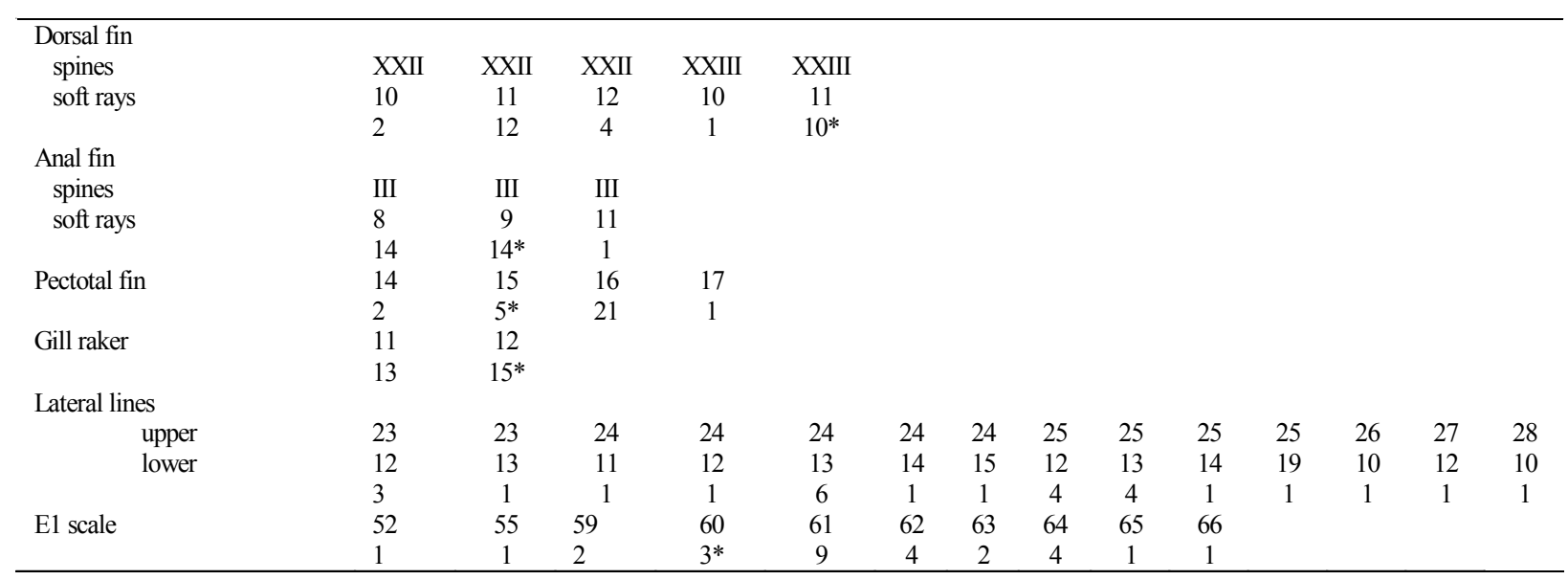


Etymology. Empeheres from Greek meaning similar, in reference to its similarity with $C$. jurubi, species habiting the same drainage. An adjective.

Comments. The specimens of $C$. empheres were collected above a major waterfall (Fig. 9) in the rio Chapecó. Many other localities were explored downstream and in the rio Uruguay itself, but no additional specimens were captured.

\section{Discussion}

Crenicichla hadrostigma and C. empheres are both included in the $C$. missioneira species group sensu Lucena \& Kullander (1992). This group, hypothesized to be monophyletic, includes C. missioneira, C. minuano, C. tendybaguassu, C. igara and C. jurubi, and is confined to the middle and upper Uruguay drainage. The relationships of $C$. celidochilus although uncertain, may also be with missioneira-group Lucena \& Kullander (1992). The new species described here increase to seven the number of species of the missioneira group and reinforce the remarkable diversification within that assemblage as pointed out by Lucena \& Kullander (1992).

Crenicichla hadrostigma, C. missioneira, C. minuano, and $C$. tendybaguassu share the particular male coloration with a number of dark spots on the caudal peduncle and a series of narrow vertical single or double-bars along the middle portion of the body flank. In Crenicichla hadrostigma and C. minuano the snout is short, slightly decurved, and the lower jaw does not project before the upper. Crenicichla empheres (males), C. igara, and C. jurubi have distinctive irregular pattern of dark spots on the sides but $C$. igara differs in snout shape.

The pharyngeal bone or tooth plates of C. hadrostigma with strong teeth and without recurved cusps is distinctive of that of C. jurubi which has molariform teeth. Despite this, both species have a similar diet of almost exclusively snails. In the other species of the missioneira-group, including $C$. empheres, the tooth plate has subconical and recurved cusps teeth, and the stomach contents include aquatic insect larvae and adults. Lucena \& Kullander (1992) pointed out the presence in stomachs and intestine of the holotype of $C$. minuano (x-radiography) of crammed with mollusk shells. The small

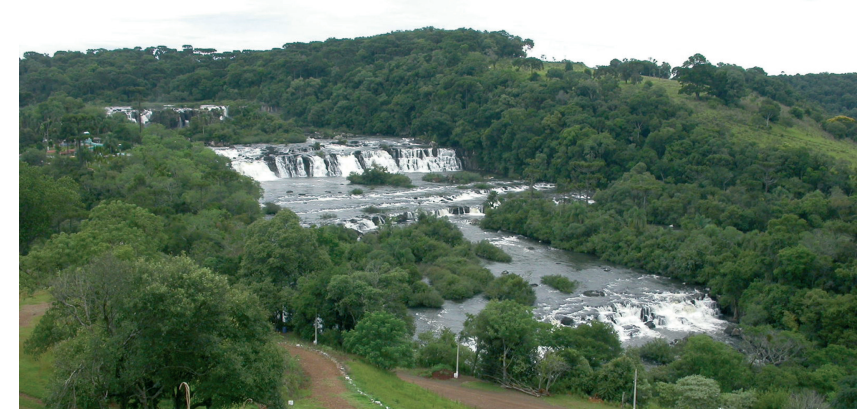

Fig. 9. Rio Chapecó, at Abelardo Luz, Santa Catarina. The specimens of $C$. empheres were collected above the waterfalls. number of stomachs analyzed of $C$. hadrostigma and $C$. minuano prevent us from making definitive conclusions, but the preliminary results suggest that the tooth plate and its dentition in these species may be intermediate between $C$. jurubi and the remaining species of the $C$. missioneira group.

\section{Acknowledgments}

The present study was supported by $\mathrm{CNPq}$ (process $n^{\circ}$.475253/2004-3). Lisiane Hahn and Luiz F. Câmara brought the first specimens of $C$. hadrostigma to my attention in the years of 1997 and 1999; Leandro Baucke helped on field activities. Thanks to Edson Pereira, José Francisco P. da Silva, Tiago Carvalho, and Vinicius Bertaco, all from MCP, for untiring dedication in field in the search of specimens of Crenicichla, and to José Francisco for the pictures. Many thanks to Sven Kullander (Swedish Museum of Natural History) for the corrections of English language and valuable suggestions to the manuscript. Two anonymous reviewers greatly improved this manuscript.

\section{Literature Cited}

Kullander, S. O. 1986. Cichlid fishes of the Amazon river drainage of Peru. Swedish Museum of Natural History, Stockholm, 431p.

Kullander, S. O. 2003. Family Cichlidae. Pp. 605-654. In: R. E. Reis, S. O. Kullander \& C. J. Ferraris (Eds.). Check list of the freshwater fishes of South and Central America. Edipucrs, Porto Alegre, 729p.

Kullander, S. O. \& C. A. S. Lucena. 2006. A review of the species of Crenicichla (Teleostei: Cichlidae) from the Atlantic coastal rivers of southeastern Brazil from Bahia to Rio Grande do Sul, with descriptions of three new species. Neotropical Ichthyology, 42(2): $127-146$

Lucena, C.A. S. \& S. O. Kullander. 1992. The Crenicichla (Teleostei: Cichlidae) species of the Uruguay River drainage in Brazil. Ichthyological Explorations Freshwaters, 3(2): 97-160

Ploeg, A. 1991. Revision of the South American cichlid genus Crenicichla Heckel, 1840 with descriptions of fifteen new species and considerations on species groups, phylogeny and biogeography (Pisces, Perciformes, Cichlidae). Ph.D. Thesis. Amsterdam. Academisch Proefschrift, Universiteit van Amsterdam. 152p.

Taylor, W. R. \& G. Van Dyke. 1985. Revised procedures for staining and clearing small fishes and other vertebrates for bone and cartilage study. Cybium, 9(2): 107-119.

Submitted April 2007 Accepted October 2007 